\title{
MUNDO IMAGINAL, ESPAÇO EDÉNICO E METAMORFOSE EM IBN 'ARABĪ E MARIA GABRIELA LLANSOL
}

Paulo Borges (Departamento de Filosofia da Faculdade de Letras da Universidade de Lisboa / Centro de Filosofia da Universidade de Lisboa)

Recebido a 2/12/2018. Aceite a 10/4/2019.

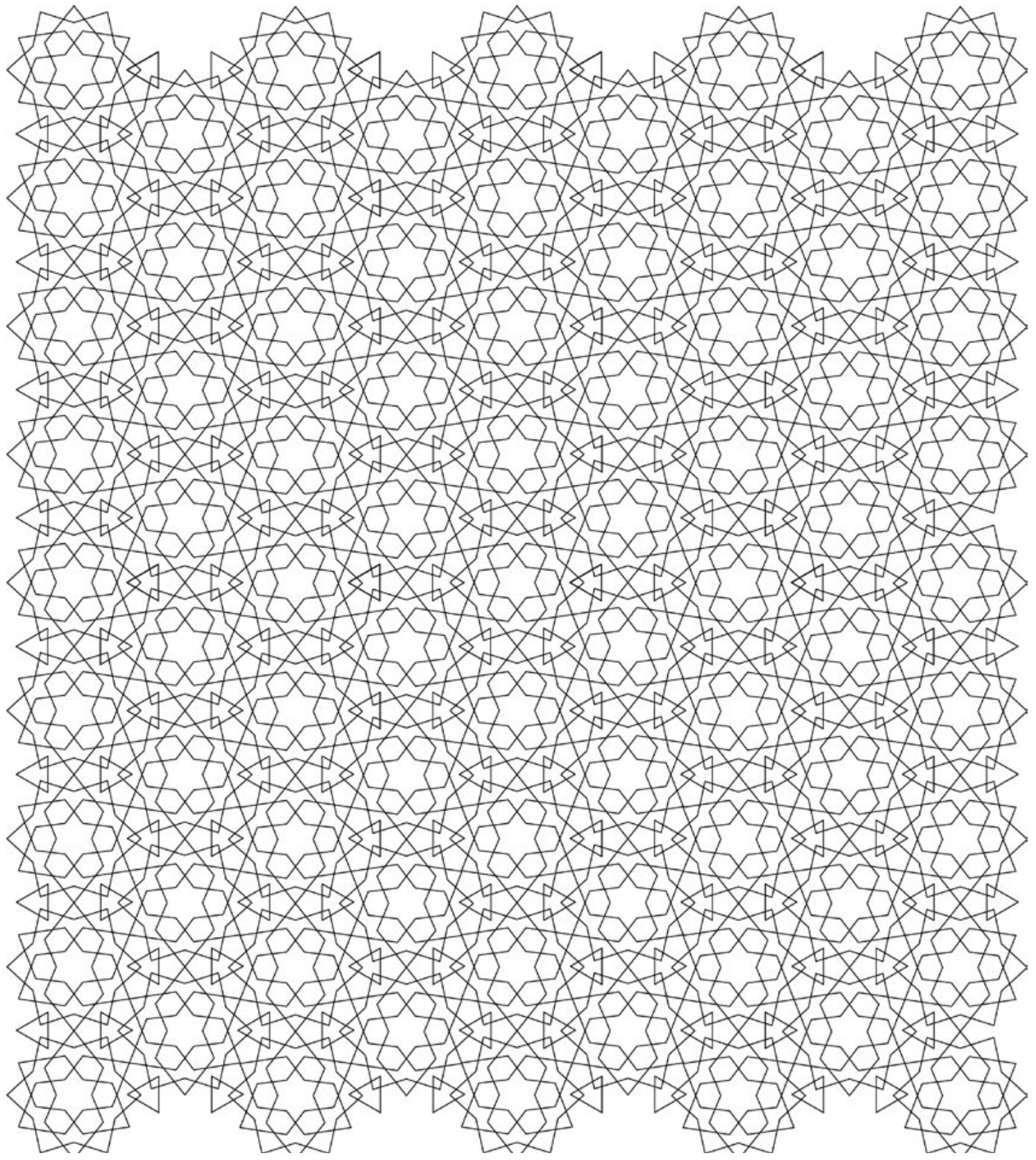


Resumo: Procuramos apresentar as noções de «mundo imaginal»e «espaço edénico» no filósofo e místico murciano e na escritora portuguesa e mostrar as suas relações como via para compreender a experiência da metamorfose da vida enquanto alternativa ao princípio de identidade prevalecente na tradição filosófica ocidental.

Palavras-chave: Ibn 'Arabī. Maria Gabriela Llansol. Mundo imaginal. Espaço edénico. Metamorfose.

Abstract: We aim to present the notions of «imaginal world» and «Edenic space» in the philosopher and mystic from Murcia, Ibn 'Arabī, and in the perspective of the Portuguese writer Maria Gabriela Llansol, in order to show their relations as a way to understand the experience of the metamorphosis of life as an alternative to the principle of identity, which prevails in the Western philosophical tradition.

Keywords: Ibn 'Arabī. Maria Gabriela Llansol. Imaginal world. Edenic space. Metamorphosis.

O objectivo deste estudo não é investigar a presença da figura de Ibn 'Arabī em Maria Gabriela Llansol, mas apresentar as noções de «mundo imaginal» e «espaço edénico» ${ }^{1}$ no filósofo e místico murciano e na escritora portuguesa, mostrando as suas relações e explorando-as como via para compreender a experiência da metamorfose da vida enquanto alternativa ao princípio de identidade prevalecente na tradição filosófica ocidental.

A deriva do pensamento ocidental dominante para a busca de uma segurança ontognosiológica, e também política, pelo sacrifício da natureza metamórfica do mundo a um pressuposto princípio de identidade lógico-metafísica, pode reconhecer-se em momentos capitais do pensamento platónico. Destacamos o Teeteto, onde Platão, após identificar sabedoria (sophia) com conhecimento (épistémè) ${ }^{2}$, rejeita a tradição mitopoética grega por fazer «de todas as coisas uma progenitura do escoamento e do movimento» ${ }^{3}$ e por não haver assim nada que exista em si e por si ao qual convenha o nome «ser», pois tudo seriam então processos e nada se poderia «estabilizar pela linguagem» ${ }^{4}$, ou seja, definir e constituir como objecto de conhecimento. Destacamos ainda a República, onde a mesma estabilização ontognosiológica do mundo busca a sua garantia numa concepção da «Divindade» na qual, ainda em contraste com a tradição mitopoética, esta não seja uma «feiticeira», capaz de se manifestar aos humanos ora sob uma forma, ora sob outra, criando «ilusões» nas suas mentes, mas antes «um ser

1 Referências bibliográficas sobre estas expressões são fornecidas no presente artigo. As traduções para a língua portuguesa de citações, frases e palavras de obras originais escritas em outras línguas são do autor do artigo, salvo diferentes indicações.

2 Cf. Platão, Teeteto, 145 e.

3 Ibid., 152 e.

4 Ibid., 157 a-c. 
sem diversidade», o menos capaz de sair da sua forma própria ${ }^{5}$ e de assumir «formas múltiplas» ${ }^{6}$. Inconfundível com as narrativas acerca das metamorfoses de Proteu e Thétis, o divino não pode «consentir em alterar-se a si mesmo», estando livre de aparições «ilusionistas» e mentirosas ${ }^{7}$. Este medo e tentativa de exorcizar a ambiguidade do mundo e sobretudo do seu princípio metafísico persiste todavia como a sombra da luz do racionalismo ocidental, com múltiplas ressurgências, desde as cartesianas hipóteses do Deus enganador e do génio maligno até à necessidade das teodiceias, que, desde Leibniz ao presente, visam justificar Deus perante a questão do mal ou da natureza ambígua da vida e do mundo.

\section{II}

Na sua visão de uma Divindade que se autorevela teofanicamente na criação de seres que a manifestam a si própria na mesma medida em que se manifesta a eles ${ }^{8}$, Ibn 'Arabī, sem abdicar da unidade do Ser, ou dessa verdade/realidade que é um dos nomes divinos (al-Haqq), considera que a sua imutabilidade se manifesta num «fluxo contínuo» pelo qual «toda a existência exibe as infinitas propriedades do Ser numa variedade caleidoscópica», na qual cada coisa a cada momento «passa por flutuação, transformação e transmutação» ${ }^{9}$. Sendo Deus em si «não-delimitado» (mutlaq), não se limita pela própria não-delimitação, podendo assim autodelimitar-se de todos os modos possíveis sem contudo jamais por eles ser delimitado, o que faz pela sua contínua e sempre diferente auto-revelação e auto-transmutação ${ }^{10}$. Como escreve o visionário de Múrcia: «Deus possui Ser Não-delimitado, mas nenhuma delimitação O impede de delimitação. Pelo contrário, Ele possui todas as delimitações. Por isso Ele é Delimitação Não-delimitada» ${ }^{11}$.

Deus manifesta a infinidade dos possíveis, designados como «não-existentes», no domínio limitado do cosmos existente, o que implica a contínua renovação ou, na verdade, a criação de cada coisa a cada instante, sem qualquer repetição ${ }^{12}$. É neste sentido que Ibn 'Arabī interpreta a passagem corânica «Cada dia Ele está nalguma tarefa» (LV, 29), entendendo «cada dia» como o «instante presente» ou o «momento indivisível» (al-zamān al-fard) e as tarefas como os sempre novos «estados (ahwāa $l$ ) das criaturas», o que faz do «camaleão» o animal que mais claramente mostra a propriedade mutante

5 Cf. Id., República, II, 380 d.

6 Ibid., II, 381 d.

7 Cf. Ibid., II, 381 c-e.

8 Cf. Henry Corbin, L'Imagination Créatrice dans le Soufisme d'Ibn' Arabî, Paris, Flammarion, 1977, 2a ed., p. 143.

9 William C. Chittick, The Sufi Path of Knowledge: Ibn al-Arabi's Metaphysics of Imagination, Albany, State University of New York Press, 1989, p. 96.

10 Cf. Ibn 'Arabī, apud W. C. Chittick, The Sufi Path of Knoweledge, cit., p. 109. Sobre a «auto-transmutação divina» (tahawroul), cf. ibid., p. 100.

11 Ibn 'Arabī, apud W. C. Chittick, The Sufi Path of Knowledge, cit., p. 109.

12 Cf. Ibn 'Arabī, , apud W. C. Chittick, The Sufi Path of Knowledge, cit., pp. 96-97. 
do «Real» ${ }^{13}$. A «raiz» da contínua mudança externa e interna do mundo e do ser humano é assim a «divina auto-transmutação (tahawewul) em formas» sempre novas de auto-desvelamento, as quais se processam no interior da vida divina ${ }^{14}$, pois todas as «substâncias» e «acidentes» do mundo são na verdade «acidentes» da única substância que é Deus ${ }^{15}$, o que não deixa de antecipar a visão de Espinosa ${ }^{16}$ tão influente em Maria Gabriela Llansol.

Conforme o axioma sufi, lā takrār fĩ al-tağallī, «A auto-revelação nunca se repete», pois a «Vastidão Divina» engloba a infinidade do possíve ${ }^{17}$ e esta não pode manifestar-se simultaneamente na finitude da existência. Por outro lado, e numa perspectiva complementar, as diferenças de todos os existentes manifestam as diferenças das suas capacidades de receber a auto-revelação divina, as quais são diversamente limitadas e configuram objectos de crença conformes aos limites das crenças de cada crente $^{18}$. Daí o desafiante hadīt que descreve o Dia da Ressurreição no qual Deus vai aparecendo a cada grupo de pessoas numa diversidade de formas sucessivas, as quais são por elas negadas até que lhes aparece na forma da sua crença original, sendo só então reconhecido como o seu «Senhor» ${ }^{19}$. Só os gnósticos são capazes de o ver em todas as coisas e formas da sua transmutação teofânica, testemunhando-o de modo omni-abrangente em todas as doutrinas e credos ${ }^{20}$. Ao «Ser (wuğūd) omnipenetrante» da divindade corresponde o «testemunho ( $\check{s} u h \bar{u} d)$ omni-penetrante» ${ }^{21}$ que experiencia a verdade da afirmação corânica: «Para onde quer que vos volteis, aí está o Rosto de Deus» (II: 115). Daqui também os vários níveis de experiência da verdade, desde o de quem nada vê senão Deus ao de quem nada vê senão o cosmos, ao de quem nada vê (devido à «velocidade da transmutação e falta de estabilidade» da manifestação) e ao do próprio Ibn 'Arabī que proclama «Nunca vi coisa alguma sem ver Deus antes dela» ${ }^{22}$.

13 Ibn 'Arabī, , apud W. C. Chittick, The Sufi Path of Knowledge, cit., pp. 98-99. Sobre a referida passagem do Alcorão, cf. Mansour Challita (tr.), O Alcorão: Livro Sagrado do Islã, Rio de Janeiro, BestBolso, 201 1, p. 417: «Cada dia lhe traz novas tarefas.».

14 Cf. Ibn 'Arabī, apud W. C. Chittick, The Sufi Path of Knowledge, cit., p. 100.

15 Cf. Ibn 'Arabī, apud W. C. Chittick, The Sufi Path of Knowledge, cit., p. 97: «Na raiz a substância do cosmos é uma. Ela muda da sua realidade. Toda a forma que se torna manifesta no seu interior é um acidente que na verdade (fi nafs al-amr) sofre transmutação (istihāla) em cada instante indivisível (zamān fard)».

16 Sobre Llansol e Espinosa, cf. Cristiana Vasconcelos Rodrigues, «Espinosa e Llansol: a troca de pensamento e afecto», in João Barrento (ed.), Europa em sobreimpressão: Llansol e as dobras da história, Lisboa, Assírio \& Alvim-Espaço Llansol, 2011, pp. 147-175.

17 Cf. Ibn 'Arabī, apud W. C. Chittick, The Sufi Path of Knowledge, cit., pp. 103-104.

18 Cf. Ibn 'Arabī, apud W. C. Chittick, The Sufi Path of Knowledge, cit., pp. 103-104; e W. C. Chittick, ibid.

19 W. C. Chittick, Ibid., p. 100.

20 Cf. Ibn 'Arabī, , apud W. C. Chittick, The Sufi Path of Knowledge, cit., p. 100; e W. C. Chittick, ibid., pp. $110-$ 111. Cf. W. C. Chittick, Mundos Imaginales: Ibn al-Arabī y la diversidad de las creencias, [s. 1.], Mandala, 2004.

21 No original: «wujūd»; «shuhūd».

22 Ibn 'Arabī, apud W. C. Chittick, The Sufi Path of Knowledge, cit., p. 102. Sobre a mencionada passagem do Corão, cf. M. Challita (tr.), O Alcorão, cit., p. 39: «Para onde vos tornardes, lá encontrareis o semblante de Deus.». 
Há assim uma radical ambiguidade ontológica inerente à natureza do cosmos, uma vez que este, sendo por um lado «tudo o que é outro do que Deus», tem noutro sentido a própria divindade como a sua «raiz», dado que, na visão de Ibn 'Arabī, «não há ninguém no Ser/existência senão Deus». O cosmos é nesta perspectiva a forma exterior de todos os nomes divinos em «modo diferenciado (tafṣill)», tal como o ser humano é a forma exterior dos mesmos nomes em «modo indiferenciado $(i \check{g} m \bar{a} l){ }^{23}$. A ambígua relação do cosmos com o Real divino converte-o em «Ele/não Ele», o que é motivo de perplexidade $(\text { hayra })^{24}$, suprema forma de contemplação ${ }^{25}$. Daqui que o conhecimento verdadeiro da natureza das coisas não passe, no plano sempre limitado do pensamento / linguagem, por uma lógica disjuntiva «isto ou aquilo», mas antes pelo regime conjuntivo, «isto e aquilo», e apofático, «nem isto nem aquilo». O Ser é «coincidência dos opostos» (ğam $a l-a d d \bar{a} d)^{26}$, o que se aplica também à transcendência-imanência divina: tal como Deus não é limitado pela sua ilimitação, também não é apenas «incomparável», sendo também «similar», como o mostra a sua contínua, infinita e sempre diversa auto-transmutação nos fenómenos do mundo. Por isso, como escreve Ibn 'Arabī, «a maior disciplina ascética» consiste em «abster-se de o negar em qualquer forma e de o delimitar pela incomparabilidade, pois Ele é absolutamente incomparável com qualquer declaração de incomparabilidade que delimite» ${ }^{27}$.

O lugar da experiência humana desta ilimitada transmutação divina é qalb, o «coração», da mesma raiz que taqallub, que significa «alteração», «transformação», «flutuação». O coração é o Trono de Deus no microcosmos, abrangendo gnosticamente o Infinito, em contraste com o céu e a terra, que o não podem conter. $\mathrm{O}$ coração não é delimitado por «nenhum atributo específico», reunindo em si «todos os divinos nomes e atributos». A sua infinita capacidade coloca-o para além de toda a delimitação, mostrando-o afim ao próprio Ser. Se a razão se esforça por definir Deus, encerrando-o nos limites de uma transcendência ou incomparabilidade unilateral, o coração liberta-o e absolve-o de todas as limitações, experienciando o absoluto na ilimitada vidência/vivência das metamorfoses divinas $^{28}$. É no coração que se manifesta a estação espiritual da ânsia ou nostalgia (rag̉ba) da realidade, que segundo Ibn 'Arabī conduz à estação da «estabilidade na variegação» ${ }^{29}$. Como escreve, «A taça do amor é o coração do amante», não a razão ou a percepção sensorial, pois estas pertencem

23 W. C. Chittick, The Sufi Path of Knowledge, cit., p. 114. No original: «ïmāl».

24 Cf. Ibn 'Arabī, apud W. C. Chittick, The Sufi Path of Knowledge, cit., pp. 114-115.

25 Cf. Paulo Borges, «A Perplexidade em Ibn 'Arabî (ou do regresso à Presença anterior à filosofia). Uma reflexão sobre a sabedoria sufi a partir de María Zambrano», in id., Vazio e Plenitude ou o Mundo às Avessas. Estudos e ensaios sobre espiritualidade, religião, diálogo inter-religioso e encontro trans-religioso, Lisboa, Âncora Editora, 2018, pp. 129-148; cf. Id. «Regressar à presença anterior à filosofia: a perplexidade em Ibn 'Arabī - uma reflexão a partir de María Zambrano», El Azufre Rojo - Revista de Estúdios sobre Ibn Arabi, n. ${ }^{\circ}$ 4, pp. 8-21.

26 W. C. Chittick, The Sufi Path of Knowledge, cit. p. 112.

27 Ibn 'Arabī, apud W. C. Chittick, The Sufi Path of Knowledge, cit., p. 112; e W. C. Chittick, Ibid., pp. $109-110$.

28 Cf. Ibid., pp. 106-107. É sabido que, nas passagens sobre o coração como Trono de Deus que é capaz de abranger o Infinito, Ibn 'Arabī está a interpretar textos tradicionais islâmicos do tipo hadīth qudsī («dito sagrado», «dito divino»).

29 Ibid., pp. 107-108. 
ao «mundo da delimitação» e só o coração «flutua de estado para estado», acompanhando a divina autotransformação nas formas do mundo e conhecendo e amando Deus nas suas contínuas e sempre novas metamorfoses ${ }^{30}$.

A faculdade com que o coração percepciona estas metamorfoses divinas é a imaginação, hayyal, a qual corresponde ao «mundo imaginal» que é simultaneamente, no plano microcósmico, a «alma» e, no plano macrocósmico, a instância intermédia da manifestação que conjuga os opostos conferindo formas sensoriais, corpóreas e existentes aos sentidos inteligíveis espirituais e não-existentes, imanifestados ${ }^{31}$. Num outro sentido, todo o cosmos não é senão «imaginação» ${ }^{32}$, pois reside entre o real (wuğūd) e o nada absolutos ${ }^{33}$. Se o visionário sufi usa o termo hayāl para designar tanto a faculdade imaginativa quanto o mundo objectivo enquanto «imaginação», frequentemente emprega o termo mițāl (imagem, de uma raiz que significa «aparecer na semelhança de») como sinónimo de «imaginação», mas neste caso sem designar a faculdade imaginativa ${ }^{34}$. A raiz de mițāl aparece na palavra tamattul, com o significado de «aparecer na imagem de» ou «tornar-se imaginalizado», que no Alcorão refere a aparição de Gabriel a Maria na Anunciação: «Ele tornou-se imaginalizado para ela como um homem sem falta» (XIX: 17) ${ }^{35}$.

Enquanto processo intermédio, a imaginação é afim à radical ambiguidade da constituição do mundo, convocando para a designar a mesma lógica da conjunção dos opostos ou da sua superação apofática: isto e aquilo e nem isto nem aquilo. Neste sentido, é o barzah (istmo) por excelência: algo que simultaneamente une e separa duas coisas, tendo atributos de ambas, mas não sendo uma nem a outra ${ }^{36}$. «O cosmos é Imaginação Não-delimitada» pois a sua «contínua criação e constante transformação» é a aparição de «Ele/não Ele». Como diz Ibn 'Arabī: «A realidade da imaginação é mudança contínua em todo o estado e manifestação em toda a forma», sendo o próprio processo de autotransformação da divina e imutável «Essência do Real» ${ }^{37}$.

Se o conhecimento supremo de Deus exige conjugar razão e imaginação, vendo-o simultaneamente incomparável e similar, pois se a tudo transcende em tudo se automanifesta ${ }^{38}$, essa ambiguidade abarca, como vimos, todo o cosmos e tudo o que contém, que são Ele/não Ele, identidade/alteridade,

30 Cf. Ibid., pp. 108-109.

31 Cf. Ibid., p. 115. Cf. W. C. Chittick, Mundos Imaginales, cit., pp. 136-138.

32 Id., The Sufi Path of Knowledge, cit., p. 116.

33 Cf. Ibn 'Arabī, apud W. C. Chittick, Mundos Imaginales, cit., p. 50. Sobre os vários sentidos da imaginação, cf. ibid., pp. 47-50, 134-138.

34 Cf. W. C. Chittick, The Sufi Path of Knowledge, cit., p. 117.

35 Ibid. Cf. M. Challita (tr.), O Alcorão, cit., p. 240: «E Nós lhe enviamos Nosso espírito sob a forma de um homem perfeito.».

36 Cf. Ibn 'Arabī, apud W. C. Chittick, The Sufi Path of Knowledge, cit., pp. 117; e W. C. Chittick, Ibid., pp. 117118. Cf. W. C. Chittick, Mundos Imaginales, cit., pp. 134-135.

37 Ibn 'Arabī, apud W. C. Chittick, The Sufi Path of Knowledge, cit., p. 118.

38 Cf. W. C. Chittick, Mundos Imaginales, cit., pp. 46, 138-139. 
ser/não ser. É neste sentido que Ibn 'Arabī, em Futūhāt al-Makkīyah, num desafiador questionamento do argumento de Platão no livro II da República, declara que «o inteiro cosmos é feitiçaria» e que os humanos estão como que enfeitiçados ao verem-no como algo independente de Deus, quando na verdade é «imaginal» e semelhante a um «sonho» ou «mera imagem» que, seja externa ou interna, reflecte sempre outra coisa, carecendo por isso de interpretação ${ }^{39}$. O ser humano é assim «um sonhador no estado» em que crê ser «dono da vigília e da consciência» e por isso tudo em que está imerso é uma «questão imaginal cujo propósito é outra coisa» ${ }^{40}$.

A constituição imaginal do mundo faz com que seja através de formas imaginais que específicas auto-revelações divinas se processem, nos sonhos ou em estado de vigília, designando-se neste caso como «imaginalização», pela qual um significado inteligível ou um anjo assume uma forma sensorialmente percepcionada por alguns ou por todos os humanos ${ }^{41}$. Estas semelhanças são todavia divinamente estabelecidas, sendo interditas à arbitrária criação humana, com excepção dos que conhecem as semelhanças que Deus gera para si, os profetas e os amigos de Deus, que podem incluir os poetas ${ }^{42}$. Todos estes são os mediadores destas formas arquetípicas e canónicas de autodesvelamento divino, que apreendem primeiro no plano de uma subtil sensorialidade imaginal e expressam depois no plano sensorial corpóreo. No caso dos poetas, colhem a sua inspiração da terceira esfera celeste, a de Vénus, habitada pelo profeta José, o grande intérprete de sonhos, que dispensa a ciência da interpretação das imagens ${ }^{43}$.

Ibn 'Arabī assume haver praticado este tipo de poesia inspirada em experiências imaginais, em sonho ou na vigília, como os encontros com espíritos corporizados descritos em Futūhāt al-Makkīyah ${ }^{44}$. Na verdade, desde Deus aos anjos ou espíritos luminosos, aos génios (ğinn) ou espíritos ígneos e aos humanos, todos têm ou podem vir a ter o poder de se manifestar a outros em formas imaginais. No caso dos humanos, a pessoa que se imaginaliza pode estar viva neste mundo ou morta neste mundo e viva no outro, o «próximo» ${ }^{45}$. Se os habitantes do mundo imaginal «adoptam a forma de todas as formas, / como água que assume a cor do vaso» ${ }^{46}$, os espíritos ao corporizar-se tornam-se todavia num certo sentido interdependentes dos humanos que os percepcionam, sustentando o mestre sufi que o olhar humano pode fixar a forma assumida pelo espírito, impedindo-o assim de a transformar ou de desaparecer, como ele próprio declara haver feito ${ }^{47}$. Há assim uma interdependência fenomenológica entre aparição e percepção.

39 Cf. Ibn 'Arabī, apud W. C. Chittick, Mundos Imaginales, cit., pp. 50-52.

40 Ibn 'Arabī, apud W. C. Chittick, Mundos Imaginales, cit., p. 52.

41 Gf. W. G. Chittick, Mundos Imaginales, cit., pp. 143-144.

42 Cf. Ibn 'Arabī apud W. G. Chittick, Mundos Imaginales, cit., pp. 146-147; e W. C. Chittick, ibid.

43 Cf. W. C. Chittick, Ibid., p. 153.

44 Cf. Ibn 'Arabī, apud W. C. Chittick, Mundos Imaginales, cit., p. 159.

45 W. C. Chittick, Ibid., p. 169.

46 Ibn 'Arabī, apud W. C. Chittick, Mundos Imaginales, cit., p. 179.

47 Cf. Ibn 'Arabī, apud W. C. Chittick, Mundos Imaginales, cit., p. 178. 
Seja como for, a imaginação, nos seus vários e correlatos níveis, não é jamais uma fantasia, mostrando antes as várias modalidades que assume a teofânica imaginação divina, desde a cosmogónica até à da imaginação activa humana, que, órgão daquela, dá forma aos seres do mundo intermédio e ao Deus que é criador e criatura no processo de se revelar a si mesmo ${ }^{48}$. Se a imaginação re-vela, ou seja, manifesta ocultando, mostrando o informe na forma, ela só vela se não for reconhecida a transparência do véu, ou seja, a trans-aparência ou aparição nas formas da sua virtude epifânica, mediante uma hermenêutica simbólica $\left(t a^{3} w \bar{i} l, t a^{3} b \bar{r} r\right)^{49}$. Segundo Henry Corbin, no livro sobre a imaginação criadora em Ibn 'Arabī, influente em Gabriela Llansol e presente na sua biblioteca ${ }^{50}$, a imaginação é inseparável da criação, entendida nem como ex nihilo, nem como emanação, em termos neoplatónicos, mas antes como uma auto-iluminação divina, que desvela e actualiza as «possibilidades eternamente latentes» na divindade abscôndita ${ }^{51}$. A imaginação é sempre intermediária e mediadora, sendo um dos níveis dessa mediação o mundo imaginal ('ālam al-mițāl), onde o espiritual se corporiza e o corpóreo se espiritualiza num plano subtil, tecido de «matéria imaterial» ${ }^{52}$. Se não é possível dissociar os aspectos teofânicos, cosmogónicos e psicológicos da imaginação, que radicam igualmente na «Imaginação absoluta» (hayāl mutlaq) - a própria «Nuvem primordial» que faz do universo uma teofania -, Ibn 'Arabī distingue contudo uma «imaginação conjunta» ao sujeito, de si inseparável, e uma «imaginação dissociável» de si, que subsiste em si mesma. No caso da primeira, distingue as imaginações premeditadas, conscientes e voluntárias e as espontâneas, como os sonhos durante o sono ou despertos. No caso da segunda, assume a realidade do mundo imaginal, que pode ser vista por todos, no mundo aparentemente «exterior», mas que só revela a sua dimensão epifânica ou teofânica aos que tiverem desperta a percepção subtil e mística ${ }^{53}$.

III

Passamos agora a considerar a presença e o sentido da metamorfose na escrita de Maria Gabriela Llansol, no âmbito circunscrito da trilogia Geografia de Rebeldes. Como tivemos oportunidade de escrever, num estudo recente sobre vazio e metamorfose em Fernando Pessoa e Gabriela Llansol, a escrita-vida llansoliana transcende a autora num espaço de transmutações, o Espaço Llansol ${ }^{54}$, onde se ensaia uma das maiores possibilidades da experiência poético-literária e humana: a de transgredir a normose instaurada pelo princípio de identidade predominante na razão ocidental e no pensamento categorial filosófico-científico-político-religioso, renovando uma experiência do mundo onde tudo é ainda e simultaneamente possível, como no primordial tempo do Sonho das cosmogonias indígenas

48 Cf. H. Corbin, L'Imagination Créatrice dans le Soufisme d'Ibn' Arabî, cit., pp. 141-142. Cf. também p. 146.

49 Cf. Ibid., p. 146.

50 Cf. João Barrento, A imaginação do Amor. Llansol e Ibn Arabî, [s. 1.], Espaço Llansol, 2017, pp. 44-48.

51 Cf. H. Corbin, L'Imagination Créatrice dans le Soufisme d'Ibn' Arabî, p. 167.

52 Ibid., pp. 167-168.

53 Cf. Ibid., pp. 169-170.

54 Cf. P. Borges, «Vazio, Interlúdio e Entresser. A Metamorfose de Fernando Pessoa em Maria Gabriela Llansol», in Aa. Vv., Actas do Congresso Internacional Fernando Pessoa 2017, Lisboa, Casa Fernando Pessoa, pp. 320-330. 
onde o cosmos não se emancipou ainda do caos e as formas e limites dos seres e das coisas ainda não se definiram e fixaram, não estando as suas relações sujeitas a regras e leis estáveis de causalidade. Assim sendo, o que é natural e comum é a metamorfose e aquilo que só surge como miraculoso e extraordinário após a ordem aparente do mundo se haver instalado na sua percepção convencional como uma colecção de seres, coisas e eventos fixos em géneros, espécies e indivíduos supostamente substanciais, existentes em si e por si, permanentes, independentes e separados. Num exemplo disto, escreve Roger Caillois: «Os objectos deslocavam-se por si mesmos, as canoas voavam pelos ares, os homens transformavam-se em animais e inversamente. Eles mudavam de pele em vez de envelhecer e de morrer. Todo o universo era plástico e fluido e inesgotável» ${ }^{55}$.

Era assim «possível um homem transformar-se em animal, planta ou pedra» ${ }^{56}$.

Todavia, a constituição dos seres na ordem cósmica implica o sacrifício da «existência simultânea de todas as possibilidades» e da consequente ausência de regras. Os seres ficam confinados nas suas individualidades, espécies e géneros, dá-se uma geral imobilização ontológica e surgem os interditos, a fim de se manter a legalidade instituída. O cosmos destaca-se do caos, ou do caósmico devir original, e traz consigo a morte, «como o fruto o verme», consequência da definição da vida nos viventes. A confusão das origens dá lugar à história natural e humana e às formas consideradas normais de causalidade, a ebulição metamórfica e criadora cede à vigilância que visa manter a boa ordem do criado e o ócio, a prodigalidade e a abundância são substituídos pelo trabalho, a poupança e a escassez. É importante contudo notar que o caos e o tempo mítico primordiais, com a sua pletora de possibilidades em aberto, permanecem presentes como a origem oculta do cosmos e do tempo natural e histórico e a sua mais funda virtualidade que tende constantemente a manifestar-se, violando as causalidades supostas normais na irrupção de tudo o que surge como inexplicável e desconcertante ${ }^{57}$. A obscura memória dessa infância do mundo, simultaneamente caótica e edénica, permanece também como uma «saudade do coração»" ${ }^{58}$, pois a vida no mundo determinado e ordenado é insatisfatória e despotenciada. De notar que também em Ibn 'Arabī, como vimos, a divina infinidade do possível não se pode manifestar simultaneamente na finitude da existência, fazendo com que a auto-revelação de Deus seja sempre nova.

Numa flagrante afinidade e contraste com tudo isto, A. Borges, no texto de abertura de O Livro das Comunidades, declara que «este livro é um processo de mutantes» e enquanto tal «um processo terrível», pois a «mutação» é a primeira de «três coisas que metem medo» e que são outras tantas formas

55 Roger Caillois, O Homem e o Sagrado, , tr. Geminiano Cascais, Lisboa, Edições 70, 1988, pp. 101-102.

56 Ibid., p. 104.

57 Cf. Ibid., pp. 102-103.

58 Ibid., p. 104. Sobre o devir metamórfico nas ontologias ameríndias e animistas, cf. Eduardo Viveiros de Castro, Métaphysiques Cannibales, tr. Oiara Bonilla, Paris, PUF, 2014, $4^{\mathrm{a}}$ ed., pp. 13-42; Id., A Inconstância da Alma Selvagem, São Paulo, Ubu, 2017, pp. 299-345; Davi Kopenawa, Bruce Albert, A Queda do Céu. Palavras de um xamã yanomani, tr. Beatriz Perrone-Moisés, pref. de Eduardo Viveiros de Castro, São Paulo, Companha das Letras, 2015. 
do «Vazio», enquanto espaço indeterminado, infundado («o Vazio não se apoia sobre Nada») e logo ilimitado ${ }^{59}$. A segunda coisa que mete medo é «a Tradição, segundo o espírito que muda onde sopra», e que não é a «Tradição segundo a Trama da Existência», relacionada com o «Poder» ou, na nossa leitura, com o projecto de subordinação e organização metafísica-ontológica-política do mundo, mas sim outra «Tradição, segundo o espírito da Restante Vida» ${ }^{60}$, que entendemos como a Vida autêntica, que jamais entrou e entrará no leito de Procusto da razão categorial. A terceira coisa que mete medo é «um corp 'a' escrever» essa mesma «Restante Vida», a das imprevisíveis metamorfoses, e não «o falar e negociar o produzir e explorar» dos seres e coisas supostamente dotados de identidades classificáveis porque substanciais, o que é a construção dos «acontecimentos do Poder» ${ }^{61}$, que fixa as formas do mundo para melhor as organizar e dominar.

A experiência da escrita é em Llansol a da imersão nesse espaço límbico, liminar e fluido que é o da «Restante Vida», onde se dão as transições do informe para a forma e vice-versa, ao mesmo tempo que as metamorfoses pelas quais os seres-figuras continuamente se dão à luz em novos seres-figuras que não são os mesmos nem outros, mas mesmos-outros, idênticos-diferentes. É esse espaço de indeterminação e metamorfose que uma figura llansoliana, Ana de Peñalosa, ama: não os livros, mas a sua «fonte de energia visível» nas imagens desentranhadas da «sucessão das descrições e dos conceitos» ${ }^{62}$ e que remove a escrita-leitura do plano sequencial do pensamento discursivo para a fecundar no espaço iniciático das «cenas fulgor», onde as figuras vivenciam a sua inexistência substancial: a mesma figura tem «a impressão de não existir por si própria, de ser uma transitória condição do tempo e do espaço» ${ }^{63}$.

É essa insubstancialidade que torna as figuras de Llansol osmóticas e proteicas, permitindo que se fundam, transmudem e confundam, como na «cena fulgor» onde «Nietzsche, João, Ana, Hadewijch, cavalo, urso, peixe, Eckhart» ao chamarem «uns pelos outros» é «por si mesmos» que chamam, ao mesmo tempo que se lembram «de todos os outros nomes que poderiam ter sido» ${ }^{64}$. É esta a verdadeira vida, pois, como escreve a autora, «A serpente que não pode / deixar a pele, morre», e isto torna o texto «secundário / como a água da chuva num grande mar» ${ }^{65}$. O texto é apenas o transpirar de mutações que suspendem a suposta autora «à beira de um abismo, simultaneamente rotação, elevação e queda», liquefazendo-se e tornando-se «corrente, frase, planta, pequena planta e pedra» ${ }^{66}$.

59 A. Borges, in Maria Gabriela Llansol, O Livro das Comunidades, Geografia dos Rebeldes I, seguido de Apontamentos sobre a Escola da Rua de Namur, posf. Silvina Rodrigues Lopes, Lisboa, Relógio D’Água, 1999, p. 9.

60 Ibid. .

61 Ibid., p. 10.

62 Ibid., p.75.

63 Ibid., p. 76.

64 Id., A Restante Vida, Geografia de Rebeldes II, seguido de O Pensamento de Algumas Imagens, posf. José Augusto Mourão, Lisboa, Relógio D’Água, 2001, p .48.

65 Ibid., p. 49.

66 Ibid., pp. 58-59. 
Na verdade, considerando a longa entrevista designada "O Espaço Edénico», a metamorfose parece ser a consequência radical da «comunicação fulgurante e generalizada entre todos os intervenientes ou figuras» dos seus livros, «sem nenhum privilégio para os humanos» ${ }^{67}$. Isto dá-se num espaço que, ecoando o mundo imaginal em Ibn 'Arabī, se diz não um «lugar imaginário», mas um «lugar imaginante» ${ }^{68}$. É este que se nomeia como o «espaço edénico» ${ }^{69}$, espaço de comunicação-comunhão-comutação cósmica onde vigora um «acordo de criação» inter-espécies, mas que apela o humano ao arriscar da sua identidade - porventura por ser o que a tem simultaneamente mais vincada e mais susceptível de abandono - na chamada «metanoite» ${ }^{70}$. $\mathrm{O}$ «espaço edénico», inconfundível com a leitura convencional do Éden bíblico, não está «na origem do universo», tendo antes sempre existido e sendo «criado no meio da coisa», como algo não fixo e «elaborável segundo o desejo criador do homem», que pode desaparecer e aparecer aqui e ali, em contraste e confronto com a fixidez das identificações sociais e com a «opressão política» que as sustenta e preserva ${ }^{71}$. «Presentes na inocência», as «imagens edénicas» ${ }^{72}$ emergem convidando as pessoas a converterem-se em «figuras» que se metamorfoseiam no processo subtil e inaparente da escrita profunda. Neste, «à medida que perdem o medo» e se evadem da «impostura da língua» (tendente à fixação gramatical, semântica e ontológica), abrem-se a «um grande desejo de jogo, de viagem, de paisagem aberta» e começam a adquirir o corpo do «espaço edénico» ${ }^{73}$, que é também o de uma sensibilidade aguda e profunda ${ }^{74}$, de um erotismo dos afectos e de uma «pujança» que rompe a clausura e o condicionamento da vida convencional $^{75}$, desocultando uma «presença insondável», que Llansol se recusa a teologizar ${ }^{76}$.

É nesta recusa de teologizar o ilimitado que porventura reside a maior diferença entre Llansol e Ibn 'Arabī, com consequências ao nível da concepção da contínua metamorfose do mundo que aproximam e fazem divergir «mundo imaginal» e «espaço edénico». Enquanto em Ibn 'Arabī o processo de auto-manifestação e auto-transmutação divina assume no «mundo imaginal» modalidades arquetípicas que fundam mas regulam o espaço e as possibilidades de uma criatividade humana irredutível ao arbitrário da fantasia, já em Gabriela Llansol a experiência do «espaço edénico» e do «lugar imaginante», embora claramente distinto de um «lugar imaginário», parece ser, como ela escreve, mais «elaborável segundo o desejo criador do homem» e assim mais interdependente de uma exploração heurística e lúdica que não se subordina a nenhum processo formal de revelação e parece estar mais

67 Id., Na Casa de Fulho e Agosto, Geografia de Rebeldes III, seguido de O Espaço Edénico, posfácio de João Barrento, Lisboa, Relógio D’Água, 2003, p. 141.

68 Ibid., p. 142.

69 Ibid., p. 146.

70 Ibid., pp. 143. Cf. também p. 166.

71 Ibid., p. 146.

72 Ibid., p. 147.

73 Ibid., p. 151.

74 Cf. Ibid., p. 152.

75 Cf. Ibid., p. 157.

76 Cf. Ibid., p. 166. 
perto das mutações selvagens do tempo do Sonho das cosmogonias do animismo indígena. Dito isto, emerge em ambos os autores, com toda a diversidade de contextos e experiências em que se inserem, uma clara alternativa à hegemonia do princípio de identidade no pensamento ocidental clássico e ao seu projecto metafísico-científico-político de cristalizar a experiência e percepção do mundo em formas fixas que se possam irredutivelmente distinguir, classificar e subordinar.

\section{REFERÊNGIAS BIBLIOGRÁFICAS}

BARRENTO, João (2017), A imaginação do Amor. Llansol e Ibn Arab̂̂, [s. 1.], Espaço Llansol.

BORGES, Paulo (2018), «A Perplexidade em Ibn 'Arabî (ou do regresso à Presença anterior à filosofia). Uma reflexão sobre a sabedoria sufi a partir de María Zambrano», in Id., Vazio e Plenitude ou o Mundo às Avessas. Estudos e ensaios sobre espiritualidade, religião, diálogo inter-religioso e encontro trans-religioso, Lisboa, Âncora, pp. 129-148.

(2017), «Regressar à presença anterior à filosofia: a perplexidade em Ibn 'Arabī - uma reflexão a partir de María Zambrano», El Azufre Rojo - Revista de Estúdios sobre Ibn Arabi, n. ${ }^{\circ}$ 4, pp. 8-21,

https://revistas.um.es/azufre/article/view/314761.

(2017), «Vazio, Interlúdio e Entresser. A Metamorfose de Fernando Pessoa em Maria Gabriela Llansol», in Aa. Vv., Actas do Congresso Internacional Fernando Pessoa 2017, Lisboa, Casa Fernando Pessoa, pp. 320-330,

https://casafernandopessoa.pt/application/files/5315/1698/3454/CFP_ACTAS_2017.pdf.

CAILLOIS, Roger (1988), O Homem e o Sagrado, tr. Geminiano Cascais, Lisboa, Edições 70.

CASTRO, Eduardo Viveiros de (2017), A Inconstância da Alma Selvagem, São Paulo, Ubu.

(2014), Métaphysiques Cannibales, tr. Oiara Bonilla, Paris, PUF, $4^{\mathrm{a}}$ ed.

CHALLITA, Mansour (tr.), O Alcorão: Livro Sagrado do Islã, Rio de Janeiro, BestBolso, 2011.

CHITTICK, William G. (2004), Mundos Imaginales: Ibn al-Arab̄̄ y la diversidad de las creencias, [s. 1.], Mandala.

(1989), The Sufi Path of Knowledge: Ibn al-Arabi's Metaphysics of Imagination, Albany, State University of New York Press.

CORBIN, Henry (1977), L'Imagination Créatrice dans le Soufisme d'Ibn' Arabî, Paris, Flammarion, 2a ed. 
KOPENAWA, Davi, ALBERT, Bruce (2015), A Queda do Céu. Palavras de um xamã yanomani, tr. Beatriz Perrone-Moisés, pref. Eduardo Viveiros de Castro, São Paulo, Companha das Letras.

LLANSOL, Maria Gabriela (2003), Na Casa de Julho e Agosto, Geografia de Rebeldes III, seguido de O Espaço Edénico, posf. de João Barrento, Lisboa, Relógio D’Água.

(2001), A Restante Vida, Geografia de Rebeldes II, seguido de O Pensamento de Algumas Imagens, posf. José Augusto Mourão, Lisboa, Relógio D’Água.

_ (1999), O Livro das Comunidades, Geografia de Rebeldes I, seguido de Apontamentos sobre a Escola da Rua de Namur, posf. Silvina Rodrigues Lopes, Lisboa, Relógio D’Água.

RODRIGUES, Gristiana Vasconcelos (2001), «Espinosa e Llansol: a troca de pensamento e afecto», in João Barrento (ed.), Europa em sobreimpressão: Llansol e as dobras da história, Lisboa, Assírio \& Alvim-Espaço Llansol, pp. 147-175.

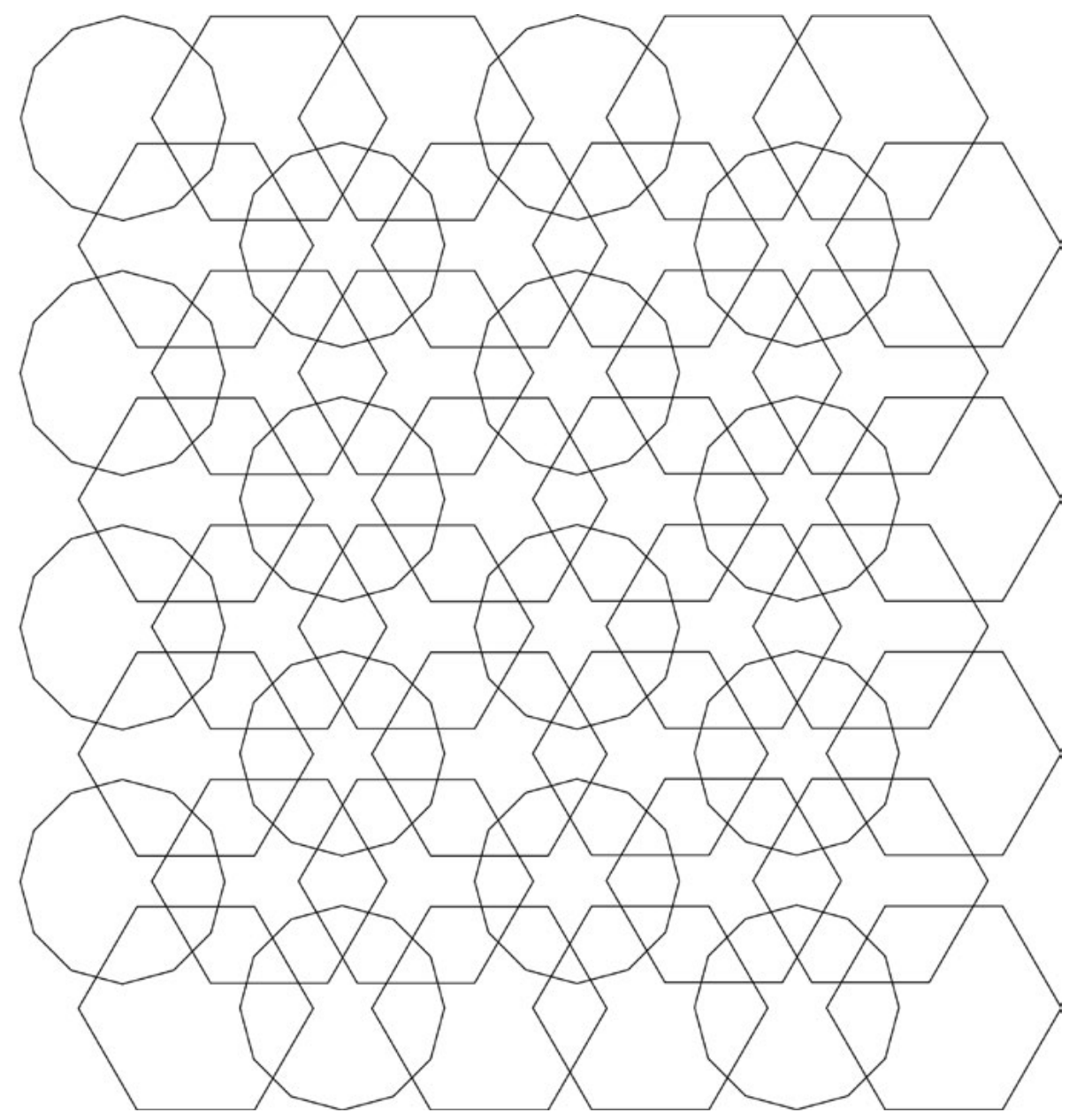

